\author{
Joanna Sobiesiak \\ (Uniwersytet Marii Curie-Skłodowskiej)
}

\title{
Kilka uwag o książce Martina Wihody, První česká království, Praha 2015, ss. 440
}

\author{
Some Remarks on the Book of Martin Wihoda, První česká království, \\ Praha 2015, pp. 440
}

\section{STRESZCZENIE}

Książka dotyczy problematyki związanej z okolicznościami otrzymania przez władców z dynastii Przemyślidów korony królewskiej i zakorzenienia się w Czechach dziedzicznej monarchii. Odwołując się do koncepcji Kantorowicza, Autor stawia pytanie o naturę pierwszego czeskiego królestwa. Czy było ono tworem pragmatycznym, czy samoświadomie-charyzmatycznym i jak ideę królestwa postrzegały czeskie elity.

Martin Wihoda starał się wykazać, jak doszło do powstania w Czechach idei królestwa, które stanowi wartość samą w sobie i nie zależało od wyjątkowości osoby, która aktualnie zasiadała na tronie. Autor wskazał także na proces przyjmowania tych nowych wyobrażeń o państwie i władzy przez czeskie elity polityczne.

Słowa kluczowe: Czechy, Przemyślidzi, Praga, czeskie królestwo, Karol IV

Martin Wihoda jest profesorem Uniwersytetu Masaryka w Brnie. Choć można go zaliczyć do mediewistów młodszego pokolenia, przez swoje badania, dorobek naukowy i międzynarodową pozycję w świecie akademickim jest obecnie bez wątpienia jednym z czołowych czeskich badaczy epoki średniowiecza. Prezentowana książka jest kolejną w dorobku naukowym M. Wihody. Do tej pory opublikował on już kilka monografii poświęconych historii ziem czeskich w wiekach średnich w szerokim kontekście europejskim. Z ważniejszych można wymienić choćby: Zlatá bula sicilská. Podivuhodný př́běh ve vrstvách paměti, Praha 2005 - która ukazała się 
też w wersji niemieckojęzycznej ${ }^{1}$, Vladislav Jindřich, Brno 2007, wydana ostatnio po angielsku przez prestiżowe wydawnictwo Brill ${ }^{2}$, czy jedna z nowszych Morava v době knížecí 906-1197, Praha 2010.

Jak widać, zainteresowania Autora po równo rozkładają się na problemy związane z historią Morawy, co jest niejako naturalne, zważywszy na miejsce pracy M. Wihody, jak i na dzieje całego państwa czeskiego. Prezentowana publikacja zalicza się właśnie do tej drugiej kategorii. Książka zatytułowana Proní česká královstuí odnosi się do problematyki związanej z okolicznościami otrzymania przez władców z dynastii Przemyślidów korony królewskiej i zakorzenienia się w Czechach dziedzicznej monarchii. Jak wiemy, średniowieczne Czechy, w odróżnieniu od innych państw regionu, dosyć późno, bo dopiero u schyłku XII w. stały się państwem o ustalonej władzy królewskiej. Wcześniej, i to jest ewenementem na skalę europejską, władcy z dynastii Przemyślidów, dwukrotnie obdarzani byli koroną królewską (Wratysław [II] I w 1085 i Władysław I [II] w 1158), za każdym jednak razem było to wyróżnienie indywidualne, które nie niosło za sobą ustanowienia w Czechach monarchii dziedzicznej ${ }^{3}$. Dopiero w ostatnich latach XII w., za panowania Przemysła Ottokara I, zacięte rozgrywki polityczne między pretendentami do władzy w Rzeszy, w których czynnie uczestniczył papież, pozwoliły Przemyślidom utrzymać na stałe koronę jako fawor przynależny czeskim władcom.

Czytelnik, który zasugerował się tytułem publikacji, będzie oczekiwał, że w książce wyłożono zagadnienia omawiające właśnie te dwa (bądź trzy) pierwsze przypadki otrzymania korony królewskiej przez przemyślidzkich dynastów. Tymczasem już rzut oka na spis treści uświadamia, że otrzymujemy szeroki chronologicznie i problematycznie wykład, w którym równie dużo miejsca poświęcono, skądinąd bardzo ważnej dla legitymizacji władzy w Czechach, legendzie dynastycznej Przemyślidów czy rządom Karola IV Luksemburga i jego działaniom na rzecz umocnienia władzy w Czechach, jak i problemom dwu pierwszych Przemyślidzkich koronacji czy poczynaniom politycznym Przemysła Ottokara I.

Publikacja składa się aż z dziewięciu rozdziałów, z których każdy podzielony jest na kilka zatytułowanych podrozdziałów.

${ }^{1}$ M. Wihoda, Die Sizilischen goldenen Bullen von 1212: Kaiser Friedrichs II. Privilegien für die Přmysliden im Erinnerungsdiskurs. Forschungen zur Kaiser- und Papstgeschichte des Mittelalters 33, Wien-Köln 2012.

${ }^{2}$ M. Wihoda, Vladislaus Henry. The Formation of Moravian Identity, Leiden-Boston 2015.

${ }^{3}$ V. Vaníček, Vratislav II. (I.) Proní český kral. Čechy v době evropského kulturního obratu v 11. století, Vyšehrad 2004, s. 183; J. Žemlička, Křižovatky Vladislava II. Co mohl či nemohl druhý český král, w: Vladislav II. druhý král z Přemyslova rodu. K 850. výročí jeho korunovace, red. M. Mašek, P. Sommer, J. Žemlička, Praha 2009, s. 17-27. 
Rozdział pierwszy jest właściwie teoretycznym wstępem do rozważań pomieszczonych $\mathrm{w}$ rzeczonej monografii. Autor koncentruje w nim swoją uwagę na klasycznych teoriach na naturę państwa i władzy królewskiej wybitnego niemieckiego mediewisty Ernsta Kantorowicza, zawartych w jego pracach: King's Two Bodies i Kaiser Friedrich der Zweite. Na bazie koncepcji Kantorowicza M. Wihoda stawia pytanie o naturę pierwszego czeskiego królestwa. Czy miało ono charakter pragmatyczno-tytularny, czy samoświadomie charyzmatyczny i jak ideę królestwa postrzegały czeskie elity, które przecież wybór władcy traktowały, jak swoje niezbywalne prawo. Rozdział drugi (podzielony na trzy podrozdziały), zatytułowany Kosmův Vratislav, dotyka kluczowego problemu dla recepcji idei monarchii w czeskiej społeczności, czyli stosunku do niej czeskich wielmożów. Autor prezentuje polityczne okoliczności uzyskania przez księcia Wratysława II korony. Jak wiemy, był to pierwszy Przemyślida obdarzony tą godnościa, M. Wihoda wymienia argumenty na rzecz tezy, że o królewską godność starał się (u papieża, a nie u władcy Rzeszy) też starszy brat i poprzednik Wratysława, książę Spitygniew II (1055-1061) - do tego wątku wraca też w następnych rozdziałach. W tej części pracy Autor zwraca uwagę na bardzo istotny problem w kontekście kształtowania się czeskiej monarchii, a mianowicie stosunek możnych do idei monarchii. Niechęć czeskiej wspólnoty do zaszczytów Wratysława najlepiej obrazuje opinia o tym władcy w Kronice Kosmasa, gdzie pierwszy czeski król został przedstawiony jako zdradliwy wiarołomca.

Rozdział trzeci: Paměti hrátky mámivé, również podzielony na trzy podrozdziały, dotyczy istnienia zbiorowej pamięci czy raczej wspólnej świadomości czeskiej wspólnoty o tych elementach przeszłości, które w końcu legły u podstaw ukonstytuowania się czeskiej monarchii. Ważnym składnikiem tego procesu była tradycja o słowiańskim królu Świętopełku - rozwijana jeszcze na dworze Przemysła Ottokara II - którego następcami - w znaczeniu ideologicznym - zostali Przemyślidzi. Jednak kluczowe miejsce w budowaniu idei czeskiej państwowości przypadło oczywiście patronowi kraju i ludu, czeskiemu księciu i świętemu Kościoła - Wacławowi I (923-935). Pomiędzy źródłami, które analizuje w tej części książki M. Wihoda, na szczególną uwagę zasługują Roczniki Pegawskie, które niosą istotne, nie tylko w warstwie politycznej, ale i ideologicznej, informacje odnośnie do przyjęcia przez Wratysława korony królewskiej.

Rozdział czwarty: Krajina knízecího věku, obszerniejszy od poprzednich, podzielony aż na pięć podrozdziałów, dotyczy bardzo ciekawego problemu, jakim jest zanotowana w przekazach źródłowych czeska tradycja o pochodzeniu rodzimej władzy książęcej. Rozdział ten, niezwykle bogaty $\mathrm{w}$ treści, Autor rozpoczyna od omówienia swego rodzaju fenomenu 
politycznego, jakim był wiec Czechów. Każdy z przemyślidzkich władców musiał liczyć się ze zdaniem możnych wyrażanym na wiecu, a możni z kolei z pokolenia na pokolenie przekazywali sobie aksjomat o tym, że wiece/sejmy są filarem prawnych struktur czeskiej państwowości. Przy czym jednym z ważniejszych praw przysługujących możnym był wybór księcia. Następnie M. Wihoda robi obszerny wykład o sakralnych korzeniach dynastii Przemyślidów, narodzinach prawa w czasach mitycznej wieszczki Libuszy i ustanowieniu miejsca centralnego dla wspólnoty stolicy Pragi. Wykład o podwalinach ideologicznych czeskiej państwowości uzupełnia obszerna analiza okoliczności politycznych, w wyniku których Czechy weszły w orbitę wpływów Rzeszy niemieckiej. M. Wihoda podkreśla, jak ważne dla Czechów było podporządkowanie Karolingom już w początkach IX w. Następnie czytelnik otrzymuje wnikliwą analizę poszczególnych wypadków manifestacji władzy czeskich władców, z których część łączy się z postępującym uzależnieniem państwa czeskiego od Rzeszy (od pierwszego poświadczonego przypadku udzielenia Czech w lenno księciu Władywojowi w 1002 r., przez pojawienie się w 1099 r. choragwi jako znaku państwa - ducatus insignia et vexillum, po koronację Wratysława w 1085 r.)

Krótki rozdział piąty: Nové obzory, naděje a výzvy skupia się na wypadkach pierwszej połowy XI w., kiedy książę czeski Spitygniew II rozpoczął w Rzymie starania o podniesienie diecezji praskiej do rangi metropolii (Autor wychodzi od problematycznego z punktu widzenia prawa kościelnego uwiezienia z Polski relikwii św. Wojciecha i wynikłych z tego problemów dla czeskiego księcia Brzetysława). Sytuacja zmieniła się po śmierci Brzetysława, spora samodzielność polityczna jego następcy możliwa była z racji osłabienia (po okresie panowania Henryka III w czasie regencji cesarzowej wdowy Agnieszki) nacisku ze strony Rzeszy. W efekcie, w 1059 r. Spitygniew otrzymał od papieża pozwolenie na to, aby nosił biskupią mitrę w dni świąt kościelnych, w zamian za co czeski książę obiecał płacić co roku do Rzymu sto grzywien srebra ${ }^{4}$. Dość niejasne i nieliczne wiadomości źródłowe pozwalają jednak M. Wihodzie na wyrażenie poglądu, że mitra przysłana przez papieża Mikołaja II księciu Spitygniewowi była zapowiedzią planowanej koronacji tego Przemyślidy.

Kolejny rozdział: Král Čech a Polska - obszerny i podzielony na pięć podrozdziałów - poświęcono zabiegom Wratysława II o uznanie zarówno w kraju, jak i w regionie jego królewskiej godności oraz związanych z nią monarszych ambicji. W wykładzie M. Wihody znajdziemy omówie-

${ }^{4}$ Velké dějiny zemí Koruny České, red. M. Bláhová, J. Frolík, N. Profantová, t. 1, Praha 1999, s. 414. 
nie rytuałów ostentacji władzy podejmowanych przez Wratysława i ich kontekstu $\mathrm{w}$ relacji do pozycji i prerogatyw władcy Rzeszy. Omówiono rolę i znaczenie monarszej rezydencji Wratysława na Wyszehradzie. Ważnym zagadnieniem, podejmowanym zresztą już wcześniej przez M. Wihodę ${ }^{5}$ jest problem tytułu polskiego króla, jaki zdaniem Kosmasa miał posiadać Wratysław z nadania niemieckiego króla i cesarza Henryka IV'. Bez wątpienia Wratysław był dla Henryka IV pożądanym i ważnym sojusznikiem, zarówno w potyczkach ze zbuntowanymi panami w Rzeszy, jak i w walkach w Rzymie i z tej racji możliwe jest, że czasowo cesarz zgodził się na posiadanie przez niego tytułu polskiego króla. Należy zgodzić się z Autorem, że zaszczyt ten miał raczej charakter przewagi tytularnej nad innymi władcami regionu, niż oznaczał faktyczną kontrolę nad ziemiami polskimi. Jeśli rzeczona wiadomość nie jest tylko inwencją literacką Kosmasa, władca Rzeszy mógł w ten sposób zademonstrować sprzeciw wobec kilku królewskich koronacji Piastów dokonanych bez cesarskiej aprobaty. Zresztą Henryk IV, podobnie jak kilkadziesiąt lat później Fryderyk Barbarossa - o czym M. Wihoda opowiada już w następnym rozdziale - uznawszy, że pomoc Przemyślidy nie jest mu już niezbędna, odwrócił się od swojego protegowanego i wsparł politycznie Piastów.

Rozdział siódmy: Čelenka kancléře Rainalda, złożony z trzech podrozdziałów, dotyczy okoliczności politycznych, jakie doprowadziły do obdarzenia w 1158 r. księcia czeskiego Władysława II przez cesarza Fryderyka Barbarossę koroną królewską. M. Wihoda zwraca uwagę na podobieństwo okoliczności politycznych w kontaktach czesko-niemieckich oraz istotę problemów, z jakimi borykał się w Europie niemiecki władca, które towarzyszyły zarówno pierwszej, jak i drugiej koronacji przedstawiciela dynastii Przemyślidów. W obu przypadkach korona była formą wynagrodzenia czeskiego sojusznika za pomoc już udzieloną lub taką która dopiero miała nastąpić, niemieckiemu dynaście w Italii. Za głównych inspiratorów i wykonawców politycznego planu, dzięki któremu doszło do zbliżenia politycznego Fryderyka Barbarossy i czeskiego księcia Władysława, uważa kanclerza Rainalda z Dassel i praskiego biskupa Daniela. Ten ostatni, jak przypuszcza M. Wihoda, mógł na Wielkanoc $1158 \mathrm{r}$. w Pradze dokonać pomazania Władysława świętymi olejami, tym samym sakralizując jego królewską godność. Zabieg ten, jak i inne manifestacje monarszych aspiracji Władysława, nie zostały dobrze przyjęte przez czeskich możnych. Niezadowolenie i opór wobec poczynań króla uzewnętrz-

${ }^{5}$ M. Wihoda, Polská koruna českých králů, „Český časopis historický” 2004, 102, s. 721-744.

${ }^{6}$ Cosmae Pragensis Chronica Boemorum, ed. B. Bretholz, MGH Scriptores rerum Germanicarum, Nova series, t. 2, Berlin 1923, II 37, s. 135. 
niły się najmocniej, kiedy Czesi wystąpili przeciw sukcesyjnym planom Władysława, popierając od dawna zabiegających o praski tron Udalryka, a potem Sobiesława II, synów Sobiesława I, który był wujem króla Władysława 7 .

Autor konkluduje rozdział stwierdzeniem, że następcy Władysława: jego syn Fryderyk czy stryjeczni bracia nie domagali się korony, mimo że w dokumencie z 18 stycznia 1158 r. Barbarossa potwierdził dziedziczność godności, którą obdarzył Władysława.

Rozdział kolejny, zatytułowany: Proní mezi knížaty, w znacznej części poświęcony jest opisowi poczynań politycznych czeskiego księcia Przemysła Ottokara I, w wyniku których otrzymał on królewską koronę (i to dwukrotnie! W 1198 r. zaszczytem tym obdarzył Przemyślidę Filip Szwabski, a w 1203 r. tę samą godność przyznał Przemysłowi Otto IV Brunszwicki). Znowu, tak jak w wypadku korony dla Wratysława i Władysława, na awans królewski Przemyślidy wpłynęła sytuacja polityczna w Rzeszy. Konflikt o władzę między Welfami a Staufami w 1198 r. wyniósł czeskiego księcia do rangi pożądanego sojusznika, jak się okazało dla obu zwaśnionych stron ${ }^{8}$. W konsekwencji nie tylko otrzymał królewską koronę, ale też po raz pierwszy - co podkreśla M. Wihoda - czeski król został w swojej godności uznany przez papieża, a stało się to $\mathrm{w} 1204 \mathrm{r}$. W omawianym rozdziale autor porusza niezwykle istotny problem królewsko-cesarskich dokumentów wystawionych dla czeskich królów. M. Wihoda odwołuje się do treści kilku takich aktów prawnych powstałych w XIII w. Najważniejszymi z nich są: Złota Bulla sycylijska wydana przez króla Fryderyka sycylijskiego dla czeskiego króla Przemysła Ottokara I z 26 września 1212 r.; Złota Bulla z Melfi wydana w lipcu 1231 r. przez cesarza Fryderyka II dla Wacława I i przywilej z 26 lipca 1216 r., w którym Fryderyk uznawał, że czescy możni jednogłośnie wybrali pierworodnego syna Przemysła Ottokara VI - Wacława na króla, a cesarz, spełniając prośbę praskiego dworu, nadał elektowi czeskie królestwo w lenno. Autor, na podstawie treści powyższych regulacji prawnych, zwraca uwagę, że w XIII w. przy obejmowaniu władzy w Czechach została odrzucona obowiązująca od 1055 r. zasada senioratu na rzecz primogenitury ${ }^{9}$. Jednocześnie władcy prascy, którzy bez wątpienia mieli wpływ na treść królewsko-cesarskich przywilejów, zatroszczyli się, aby w każdym z nich podkreślano rolę zgromadzenia Czechów przy wyborze kolejnego króla. M. Wihoda stwierdza nawet, że część z tych dokumentów skierowana była przede wszystkim

${ }^{7}$ J. Žemlička, Čechy v dobĕ knižecí, Praha 1997, s. 263-264.

${ }^{8}$ V. Vaníček, Velké dějiny zemí Koruny České, t. 2: (1197-1250), Praha 2000, s. 65-82.

${ }^{9}$ B. Krzemieńska, Břetislav I. Čechy a střední Evropa v prvé polovinĕ XI. století, Praha 1999, s. 374. 
do czeskich możnych, aby podkreślić ich wolne prawo do wyboru władcy, po którym dopiero miał następować ślub lenny i uznanie przez rzymsko-niemieckiego króla. Miało to zapewne nastawić przychylnie czeskich wielmożów do instytucji monarchii.

W końcowych partiach omawianego rozdziału Autor wylicza koligacje, jakie łączyły Przemyślidów z pierwszymi rodami Rzeszy. Podsumowuje stwierdzeniem, że w środkowowschodniej Rzeszy rządziły potężne familie Babenbergów, Przemyślidów, Wettynów czy Wittelsbachów, a cesarze wykorzystywali okolicznościowe animozje między nimi do utrzymania $w$ ryzach zbyt ambitnych członków tychże rodzin. Obok związków natury rodzinnej, pozycję XIII-wiecznych Przemyślidów, jako ważnego rodu w ramach struktury politycznej Rzeszy, wyznaczała wysoka pozycja czeskiego króla na cesarsko-królewskim dworze. Przekazy źródłowe potwierdzaja, że król czeski pełnił na dworze niemieckich władców funkcję cześnika, pojawia się też wiadomość o udziale czeskiego króla w elekcji władców Rzeszy. W przypadku tych zaszczytów pozycja czeskiego monarchy jako pożądanego sojusznika, podobnie jak w minionych stuleciach, skłaniała niemieckich władców do uznawania rzeczonych prerogatyw. M. Wihoda odwołuje się (pośród kilku innych przykładów) do dokumentu Rudolfa Habsburskiego z 26 września 1290 r., w którym rzymsko-niemiecki król potwierdzał przywilej sprawowania funkcji cześnika przez czeskiego króla i podkreślał, że władcy prascy powołani są do wybierania rzymsko-niemieckiego króla.

Rozdział dziewiąty, ostatni, zatytułowany: Budování obce i podzielony na cztery podrozdziały w całości jest poświęcony prawno-ideologicznym podstawom sprawowania władzy królewskiej w Czechach w XIV w., a więc w epoce Luksemburgów. Karol IV (król czeski 1346-1378, cesarz 1355), syn Elżbiety, córki króla Wacława II Przemyślidy i Jana Luksemburskiego (syn cesarza Henryka VII, król Czech od 1310) ${ }^{10}$ - zapewne starał się uchodzić przed czeską elitą polityczną za monarchę utrzymującego łączność z przyrodzoną Czechom rodzimą dynastią ${ }^{11}$. Nie zmienia to faktu, że zarówno jego panowanie, jak i rządy jego ojca bez wątpienia otworzyły zupełnie nowy rozdział w dziejach czeskiej państwowości. M. Wihoda stara się wykazać działania, za pomocą których Karol IV, odwołując się do przemyślidzkiej tradycji, legitymizował i umacniał swoją królewską władzę w Czechach. Na polecenie Karola IV dworscy kanceliści

${ }^{10}$ Lucemburkové. Česká koruna uprostřed Evropy, red. L. Bobková, F. Šmahel, Praha 2012, s. 71-84, 145 .

${ }^{11}$ E. Doležalová, Přemyslovská tradice v lucemburské době, w: Přemyslovci. Budování českého státu, red. P. Sommer, D. Třeštík, J. Žemlička, Praha 2009, s. 530-540. 
zebrali wszystkie dokumenty określające zakres królewskich uprawnień i odnoszące się do sposobu wyboru władcy, począwszy od przywilejów Fryderyka Barbarossy z 1158 r., przez wszystkie bulle wystawione przez Fryderyka II, na dokumentach Rudolfa i Albrechta Habsburgów kończąc. Akty te, na zwołanym 7 kwietnia 1348 r. przez króla do Pragi dworskim zjeździe, zostały $\mathrm{z}$ inicjatywy Karola, przedstawione zgromadzonym. Zatwierdzono też wtedy dokument, w którym podkreślano, że wybór czeskiego króla na zawsze należy do wspólnoty (obec) czeskiego królestwa. Kwietniowy akt regulował też przebieg ceremonii koronacyjnej. M. Wihoda podkreśla, że Karol w swoich działaniach, mających podkreślić legalność i splendor jego władzy, odwoływał się do czeskiego rytu intronizacyjnego, do świętych patronów wspólnoty (korona królestwa staje się koroną św. Wacława - nieśmiertelną koroną czeskiego królestwa corona regni Boemie) oraz do legendy dynastycznej Przemyślidów. W rozdziale nie mogło zabraknąć wzmianek o ogłoszonej 10 stycznia 1356 r. przez Karola IV Złotej Bulli. Szczególnie interesuja Autora te partie dokumentu, które potwierdzają dominującą na dworskich zjazdach pozycję czeskiego króla między innymi panami Rzeszy i sytuują czeskiego monarchę - jako cześnika Rzeszy między elektorami decydującymi o wyborze rzymsko-niemieckiego króla. W kontekście wątku, który zdaje się najbardziej interesować Autora, czyli funkcjonowania władzy królewskiej w Czechach, M. Wihoda odnotowuje, że Złota Bulla dawała czeskiemu królowi prawo przeniesienia królewskich przywilejów na pierworodnego potomka. W przypadku gdyby panujący król takowego nie posiadał, to o wyborze następnego władcy mieli decydować czescy możni.

Po lekturze książki okazuje się, że tytuł monografii, który sugerował, że można go odnieść do rządów pierwszych trzech czeskich królów, M. Wihoda zastosował do o wiele dłuższego okresu w dziejach czeskiej państwowości, który można określić jako Przemyślidzki. Owo tytułowe pierwsze czeskie królestwo to okres, w którym władzę sprawowali Przemyślidzi bądź władcy blisko z nimi spokrewnieni lub skoligaceni. Autor z dużą erudycją wykazuje, w jakich okolicznościach politycznych korona była ofiarowywana przemyślidzkim książętom, jakie akty prawne regulowały sposób przekazywania tej godności następcom i jakie miejsce w monarszych aspiracjach kolejnych rezydujących w Pradze królów zajmowali czescy możni. M. Wihoda przekonuje też, jak dużą wagę do rodzimej, przemyślidzkiej tradycji dynastycznej przywiązywał król z dynastii Luksemburgów - Karol IV. Szczególnego znaczenia nabiera teraz odwołanie na wstępie monografii do tez E. Kantorowicza. M. Wihoda starał się wykazać, jak doszło do powstania w Czechach idei królestwa, które stanowi wartość samą w sobie i nie zależy od wyjątkowości osoby, noszą- 
cej aktualnie koronę. Autor wskazał także na proces przyjmowania tych nowych wyobrażeń o państwie i władzy przez czeskie elity polityczne. Czytelnik otrzymuje więc wartościową i napisaną z dużą elokwencją rozprawę o ideologicznym procesie prowadzącym do powstania czeskiego królestwa.

\section{BIBLIOGRAFIA}

Cosmae Pragensis Chronica Boemorum, ed. B. Bretholz, MGH Scriptores rerum Germanicarum, Nova series, t. 2, Berlin 1923.

Doležalová E., Přemyslovská tradice v lucemburské době, w: Přemyslovci. Budování českého státu, red. P. Sommer, D. Třeštík, J. Žemlička, Praha 2009.

Krzemieńska B., Břetislav I. Čechy a střední Evropa v prvé polovinĕ XI. století, Praha 1999.

Lucemburkové. Česká koruna uprostřed Evropy, red. L. Bobková, F. Šmahel, Praha 2012.

Vaníček V., Velké dějiny zemí Koruny České, t. 2: (1197-1250), Praha 2000.

Vaníček V., Vratislav II. (I.) Proní český kral. Čechy v dobĕ evropského kulturního obratu v 11. století, Vyšehrad 2004.

Velké dẹjiny zemí Koruny České, red. M. Bláhová, J. Frolík, N. Profantová, t. 1, Praha 1999.

Wihoda M., Die Sizilischen goldenen Bullen von 1212: Kaiser Friedrichs II. Privilegien für die Přemysliden im Erinnerungsdiskurs, Forschungen zur Kaiser- und Papstgeschichte des Mittelalters 33, Wien-Köln 2012.

Wihoda M., Polská koruna českých králi̊, „Český časopis historický” 2004, 102.

Wihoda M., Vladislaus Henry. The Formation of Moravian Identity, Leiden-Boston 2015.

Žemlička J., Čechy v dobĕ knižecí, Praha 1997.

Žemlička J., Křižovatky Vladislava II. Co mohl či nemohl druhý český král, w: Vladislav II. druhý král z Přemyslova rodu. K 850. výročí jeho korunovace, red. M. Mašek, P. Sommer, J. Žemlička, Praha 2009.

\section{ABSTRACT}

The book concerns the problem related to the circumstances of the receipt of the royal crown by the Přemyslid dynasty rulers and rooting a hereditary monarchy in the Czech State. Referring to the concept of Kantorowicz, the author puts the question about the nature of the first Czech kingdom. Whether it was a pragmatic or self-consciously-charismatic product and how the idea of the kingdom was perceived by the Czech elite.

M. Wihoda tried to present the circumstances in which the idea of the kingdom emerged in the Czech State, the kingdom which is a value in itself and did not depend on the uniqueness of the person who currently served on the throne. The author also pointed out howthese new ideas about the State and power are viewed by the Czech political elite.

Key words: the Czech State, the Přemyslids, Prague, Czech kingdom, Charles IV 


\section{NOTA O AUTORZE}

Joanna Sobiesiak - dr hab., adiunkt w Zakładzie Historii Powszechnej Średniowiecznej UMCS. Zajmuje się badaniem problematyki związanej z historią średniowiecznych Czech. Jest autorką bohemistycznych monografii: Bolestaw II Przemyślida (+999) - dynasta i jego państwo, Kraków 2006 i Od Lechowego Pola (955) do Mediolanu (1158). W stużbie monarchów Rzeszy. Relacje czeskich źródet narracyjnych o wyprawach Przemyślidów, Lublin 2011. Biografia czeskiego księcia Bolesława II została wydana również w czeskiej wersji: Boleslav II. (†999), České Budějovice (Veduta) 2014. 